\title{
A Worldwide Journey through Distance Education-From the Post Office to Virtual, Augmented and Mixed Realities, and Education during the COVID-19 Pandemic
}

\author{
Agnieszka Pregowska ${ }^{1, *(\mathbb{D})}$, Karol Masztalerz ${ }^{2}\left(\mathbb{D}\right.$, Magdalena Garlińska $^{3}$ and Magdalena Osial ${ }^{4, *}$ \\ 1 Institute of Fundamental Technological Research, Polish Academy of Sciences, Pawinskiego 5B, \\ 02106 Warsaw, Poland \\ 2 Faculty of Science and Engineering, The University of Manchester, Oxford Rd, Manchester M13 9PL, UK; \\ karol.masztalerz@student.manchester.ac.uk \\ 3 National Center for Research and Development, Nowogrodzka 47a Str., 00695 Warsaw, Poland; \\ garlinska.magdalena@gmail.com \\ 4 Faculty of Chemistry, University of Warsaw, Pasteura 1 Str., 02093 Warsaw, Poland \\ * Correspondence: aprego@ippt.gov.pl (A.P.); mosial@chem.uw.edu.pl (M.O.)
}

Citation: Pregowska, A.; Masztalerz, K.; Garlińska, M.; Osial, M. A Worldwide Journey through Distance Education-From the Post Office to Virtual, Augmented and Mixed Realities, and Education during the COVID-19 Pandemic. Educ. Sci. 2021, 11, 118. https://doi.org/10.3390/ educsci11030118

Academic Editor: Jonathan Bishop

Received: 20 January 2021

Accepted: 4 March 2021

Published: 11 March 2021

Publisher's Note: MDPI stays neutral with regard to jurisdictional claims in published maps and institutional affiliations.

Copyright: (c) 2021 by the authors. Licensee MDPI, Basel, Switzerland. This article is an open access article distributed under the terms and conditions of the Creative Commons Attribution (CC BY) license (https:/ / creativecommons.org/licenses/by/ $4.0 /)$.

\begin{abstract}
Surprisingly, distance education is quite an old concept. Its origins date back to the first correspondence-based course, which took place via the postal service in Boston, USA, in the 18th century. Rapid technological developments, especially in video and audio streaming, have increased the availability of such courses and moved learning into the virtual world. Due to the ongoing COVID-19 pandemic, we are witnessing an accelerated revolution in the learning process, as nearly all forms of education have been shifted online. Will this have a destructive effect on the human psyche? Is humanity sufficiently aware and ready for such a dramatic change? Will we return to physical in-classroom studies, or is remote distance education set to become the new norm? In particular, in medicine, computer science, fine arts, or architectural design, such a rapid change in the way students learn can be quite challenging. In this paper, we provide an overview of the history of distance learning, taking into account teachers' and students' points of view in both secondary and higher education.
\end{abstract}

Keywords: distance learning; distance education; online courses

\section{Distance Education-A Short Introduction}

Today, humankind is busier than ever before. For that reason, classical education no longer suits some of us. The technological revolution has enabled learning on the go, changing the way we study forever.

Distance learning is a type of education in which students and their lecturers are separated, i.e., they reside in different physical locations, and the instruction between them is communicated using different technologies [1]. Distance education can be classified into two categories: asynchronous and synchronous learning [2]. Asynchronous distance learning is based on the interactions between the teacher and the learner at different times, such as learning from instructions on paper, listening to recorded lectures, or watching pre-recorded visual tutorials in a flexible timeframe. In turn, synchronous learning requires interactions in real-time, such as listening to live radio programs or attending live online lectures [3]. Naturally, asynchronous distance learning is older than its synchronous counterpart, as the latter was only made possible by new developments in communication technologies [4]. Both methods have become popular, and the selection of appropriate teaching methods depends on the knowledge that the learner wants to gain. Sometimes, a mix of synchronous and asynchronous teaching is used. Modern distance education uses computers and the Internet as the delivery mechanism, with at least 80 percent of the course content delivered online $[5,6]$. 
Several decades ago, to study in a given field, people had to attend classes physically, and it was impossible to start their studies without passing classification exams. Now, people only need to spend a few minutes registering online, and they can attend world-class lectures available for everyone from numerous places across the world, without leaving their home [7]. This form of education is no longer expensive, and it is not limited to only those who cannot attend classes due to important reasons like family or health issues, but to everyone. Participation is technically limited, due to the fact that this requires a computer/tablet and Internet access. Currently, online courses are available to all who wish to learn and understand something new. No matter the subject choice, courses are readily available, both for beginners and advanced students. From the basics of physics to quantum chromodynamics, everything can be learned online.

Depending on the country and the institution that organizes the online education, there are many techniques employed, such as social learning (learning through social interactions between peers) [8], gamification (incorporation of games into education, e.g., through learning platforms or video games) $[9,10]$, and personalization (customized learning with an individual approach to students' strengths and weaknesses) [11,12]. All of these methods are utilized to ensure a high retention of knowledge and good absorption of the content by the course attendees. Unlike in the past, today, online education does not require the use of a stationary computer. Content can be displayed on a tablet [13,14], a smartphone [15,16], a laptop, [17,18], or with the use of Virtual Reality (VR) goggles [19,20]. This enables students to obtain knowledge and understanding, and new solutions are being implemented globally. Nowadays, students can read and respond to emails at any time via a computer, smartphone, tablet, or other electronic devices. Instructions for students can be delivered at a lower cost than ever before, and less time is needed to deliver these instructions. This makes the use of distance education more and more viable and accessible in many cases.

During the COVID-19 pandemic, distance learning has become mainstream [21-24]. Here, we briefly discuss the beginnings and the history of distance learning, in both secondary and higher education, from the perspective of technology development, including its bilateral (from the perspectives of students and lecturers or teachers) advantages and disadvantages.

\section{Materials and Methods}

The research methodology was based on the scoping review approach [25-28]. We considered over 100 publications published from 1926 to 2021, from databases like IEEE Xplore (The Institute of Electrical and Electronics Engineers), Google Scholar, Elsevier, Directory of Open Access Journals (DOAJ), European Open Science Infrastructure (OpenAIRE), WorldCat, and other available data sources such as websites and selected government and European Union documents. The papers were selected based on their inclusion of the following keywords (and their variations): distance learning, remote learning, distance education, and online courses. The selected sources were analyzed in terms of compliance with the analyzed topic and their contribution to the development of distance learning. The analysis considers such factors as the geographical division and the form of transmission of didactic materials, where the presented media are presented in order of their appearance, including correspondence courses, radio, TV, and others. Moreover, the application of the latest technological developments, such as Virtual, Augmented, and Mixed Realities, is considered and discussed based on their usefulness as distance learning tools. The aim of the presented review was to demonstrate that distance learning is not a new paradigm. Through the systematic analysis of distance education experiences around the world, we emphasize how quickly this form of education has developed from initial postal mail (asynchronous training) to virtual teaching, and even gamification. This review presents the most important developments regarding the inclusion of electronics in everyday life and the use of recording media since the latter have allowed for the combination of asynchronous and synchronous training to become popular globally. 


\section{The Beginning}

Access to education has almost always been of the utmost importance. However, for most of human history, very few could afford the privilege of studying or learning. For centuries, education was accessible only via teachers. In general, learning took place in traditional classrooms via lectures and discussions. For example, when students wish to study at the University of Cambridge, UK, they are obliged to live within ten miles of the city center, limiting their accommodation to special colleges, leading to quite large expenses $[29,30]$. Distance education offers a response to issues associated with participants' localization and access to knowledge for a wider audience.

\subsection{Precursors}

The precursor of distance learning (formerly known as correspondence education) was Caleb Phillips, who led training in shorthand (an abbreviated symbolic writing method) via weekly lessons communicated by the United States postal service [31,32]. Interestingly, the first participants of distance courses were mostly female. In turn, in 1840, in Bath, England, Sir Isaac Pitman introduced the element of student feedback to his distance learning courses. This was a shorthand lesson, in which the lecturer sent shorthand texts using the post to their students, and the students were obliged to send them back using the same communication source for grading and corrections. After completion of the course, students obtained a certificate of expertise in stenographic shorthand skills [33]. This innovation made education more available to people of a lower financial status. Three years later, the Phonographic Correspondence Society was founded to take over the correction of shorthand exercises [34].

\subsection{America}

The first correspondence school was founded in 1873 in the United States. It was called "the Society to Encourage Studies at Home", and it was based in Boston, Massachusetts, USA. This organization was oriented toward women who came from different socio-economic classes. It aimed to provide correspondence instructions, and it functioned in this way for 24 years. One can claim that the willingness of women to acquire and expand their knowledge significantly contributed to the popularization of distance education. At the same time, the first distance degree program arose in Illinois Wesleyan College, USA [35]. The Chautauqua Movement, which was established in 1870 to expand correspondence education for adults, had a huge impact on the popularization of distance education in the USA [36]. Four years later, the movement transferred to New York State in the form of a training program for Sunday school teachers during the summer. Over time, it evolved to cover general education and the arts. A few branches of the organization also developed into correspondence courses. In 1878, the Chautauqua Literary and Scientific Circle was founded in Chautauqua, New York, USA. This was the first adult education program, in the form of a correspondence school in the United States [37]. Finally, in 1883, Chautauqua University was created. It successfully provided a broad selection of correspondence courses and summer semesters until 1892 [38]. In turn, in 1892, the University of Chicago opened the first college-level distance learning program in the United States [39]. In 1915, the National University Extension Association (known as the National University Continuing and Adult Education Association from 1980 onwards, and as the University Continuing and Adult Education Association since 1998) was formed with the aim of expanding the intellect and knowledge of all citizens [40]. Its branches mostly took the form of state universities.

In Canada, distance learning was introduced in 1889 to ensure degree opportunities for rural teachers who were unable to attend stationary courses [41]. In 1921, the Ministry of Education received a letter from one of the parents of a child who was living in a rural area. They were requesting study materials for their children, as they lived too far away from a school to attend in-person classes. As such, the first correspondence school began. 


\subsection{Europe}

In 1776, the Jagiellonian University in Krakow, Poland, opened a correspondence course dedicated to artisans and, in 1779, the University of Warsaw provided correspondence-based physics lectures $[42,43]$. Distance education played an important role in Poland, where a secret educational and academic institution was established in 1886 under Russian annexation, called Flying University. It educated many people via distance education. One of the world's most famous scientists, Maria Skłodowska-Curie, studied at this organization during her youth. Two decades later, the organization was transformed into the Society of Higher Academic Courses in Warsaw. Almost a hundred years later, in 1965, a Correspondence Education Department arose in the National Technical High School of Horticulture in Leszno [44]. In 1990, the European School of Correspondence Education in Poland was established. It taught correspondence English courses in seven countries in Central and Eastern Europe (Poland, Hungary, Romania, Russia, Ukraine, Kazakhstan, and Belarus) [42].

In turn, the first regular correspondence course was the External Programme at the University of London, which started in 1858. In 1894, the first distance learning college in the United Kingdom, i.e., Wolsey Hall, Oxford, was created. The first European distance learning degree program was established in 1858 at the University of London, and it was named the "People's University" by Charles Dickens. It was affordable and suited to students from less affluent backgrounds [45]. In Berlin, Germany, the first correspondence language school was founded in 1856 [46].

The largest distance learning universities in Europe were established in the United Kingdom (Open University, 1969) and Germany (FernUniversität in Hagen or Distance University of Hagen, 1974) [47,48]. The first one was based on the hypothesis that communication technology could bring high quality degree-level learning. The second one offers academic study to the disabled, working people, ill people, elderly, or others, who do not have the time or ability to attend traditional programs.

In Sweden, distance education stated in 1898, when Liber Hermonds institution was founded [49] by Hans Svensson Hermod, who, after returning from the United States, where he worked as an itinerant teacher, published simple worksheets in five languages (German, English, French, Spanish and Italian). The result was a magazine that one could subscribe to for CZK 3 apiece. Subscribers could then attempt to translate the text and send it back for proofreading. This was the first step toward distance learning in Sweden. Next, he developed his concept and, in 1898, opened a private school. In 1910, thanks to this school, the first baccalaureate was completed.

In France, public distance education was established in 1939 in the form of correspondence courses. In 1944, the National Centre for Distance Education (Le Centre national d'enseignement à distance) was created. In 1986, this was amalgamated into the public services and took the form of a high school, which mainly educated sick children, ex-prisoners and deportees. Lessons were then are expanded and served the following purposes: Commercial, Elementary, and Teacher Contest Preparation [50].

\subsection{Australia}

Huge distances were also a problem for populations spread over large areas, like the communities of Queensland, Australia [51]. Since 1890, the Australian people have been able to take distance learning courses at International Correspondence Schools (ICS) in Pennsylvania, USA. The Australian branch was officially registered in 1920 [52]. The history of distance education within Australia began in 1910, when the University of Queensland established a Department of Correspondence Studies, offering a correspondence-based program. Thanks to this institution, many citizens were able to obtain an education. A year later, the University of Western Australia also joined in the experiment with distance learning $[51,53]$. The establishment of correspondence-based programs enabled education to be provided to many people, most of whom resided in rural areas. One's geographical location or family status no longer played a crucial role in the enhancement of one's 
qualifications. Additionally, traveling teachers started visiting sparsely populated areas of Australia. Education provided by them was limited to the elementary level. The outbreak of World War I put an end to the itinerant form of teaching, and the Correspondence School in Bridge Street was founded. In the early twentieth century, the Department of Education implemented an itinerant teacher project. The development of Australia's postal service made it possible to use the post as a distance education tool. The first Primary Correspondence School was established there in 1922 [54]. In 1961, the Wyndham Scheme was introduced, and it offered to teach single subjects to students who were unable to complete them in full-time units for various reasons. The mail-based education systems lasted until 1967 [52]. The main disadvantage of this type of education was the one-way communication format, as the courses only contained instructions from the professors, and feedback was limited. The participants were not able to ask the professors questions or interact with other students. The development of distance learning courses in Australia and their popularity also had a spectacular influence on education in the UK, where, in 1969, the Open University was established. The extraordinary expansion of distance learning in Australia began in 1965, providing different levels of education through distance learning programs [55].

\subsection{Africa}

To provide equal opportunities for access to education for students from rural areas in Africa, in the first half of the twentieth century, universities worldwide ran various distance education programs. In 1946, the University of South Africa became the first public institution in Africa to provide a distance teaching service. Today, it is the largest facility offering this type of education on the continent [55].

The establishment of that institution opened the gate to distance education in many African regions. In 1973, the Department of Distance Education of the School of Continuing and Distance Education created the Institute of Adult Education, which was a Correspondence Unit, offering English, Economics, General Science and Mathematics, alongside many other courses. In 1995, the Distance Education Conference devised a new concept of distance education called "Accra." It offered specific distance education programs for public universities, e.g., the University of Ghana [56].

\subsection{Asia}

The beginning of distance learning in China dates back to 1979. This took the form of correspondence education via the postal service [57]. In turn, in Japan, the first case of distance learning occurred in the late $19^{\text {th }}$ century, in the form of reprints of lecturers' notes, as there were no native language textbooks [58]. The first university to implement such a system was a private one-Waseda University. It was only in 1950 that the Ministry of Education recognized correspondence schools and thus allowed them to award degrees. Correspondence studies were covered by a different accreditation system than full-time studies. This division has been preserved and holds even today.

After India gained independence, as part of its five-year plan, the government recommended that evening study and correspondence courses should be considered valid, providing them with the power to grant their students external degrees (in 1967) [59,60]. The next step undertaken by India was a delegation to the Soviet Union to observe and evaluate its system of correspondence education. Thus, distance education via the post office at the undergraduate level was initiated in 1962 at the University of Delhi in the field of the arts [61]. Next, the system of distance learning was expanded, with top universities in India establishing directorates or departments of correspondence education. One of the pioneers in this field was Annamalai University [62].

\section{Radio}

The development of radio and television has, in some sense, ended the correspondence education era. Involving radio in the teaching process allows students to hear their teachers 
in real-time. Educational broadcasting began in the early 1920s, when academic institutions started transmitting educational materials, such as college lectures. The radio was an education medium for over 80 years, and its applications include school broadcasting, teaching adults how to read, covering basic adult education, and conducting social action programming. The main goal of radio-based distance education was not limited only to direct teaching, but also to improving the motivation and mobilization of listeners. It was also a source of news and information that was not easily accessible in printed form, especially in places located far away from any libraries.

\subsection{America}

In 1906, a new teaching unit was established, the University of Wisconsin-Extension, and, one year later, an amateur wireless station later known as the WHA started broadcasting. It was the first federally licensed radio station in the field of education [63]. As a result, the radio station was very popular, but it only offered college-level education. A year later, the Ohio State Department of Education developed the Ohio School of the Air program. The same year, the National Broadcasting Company (NBC) started "The Music Appreciation Hour", which was dedicated to children. The program focused on orchestral music. Such programs began the avalanche of educational transmissions on the radio. Radio programs were inexpensive and immediately accessible, allowing quick changes to be made to the distributed teaching content in order to suit a broader audience. The Great Depression in 1929 had a significant impact on education and radio in the USA. Of the radio stations offering educational programs, only 20 percent survived this event. In 1930, the Columbia Broadcasting System (CBS) was created [64] and the Rockefeller Foundation and the Carnegie Foundation organized and funded the National Advisory Council for Radio in Education (NACRE) [64]. Moreover, in the same year, the Institute for Education by Radio (IER) in Columbus, Ohio, was established. This unit concentrated on education techniques that could be implemented via the radio. After World War I, radio stations that were owned by universities became a popular method of teaching in the United States. The first radio licenses were granted to the University of Salt Lake City, the University of Wisconsin, and the University of Minnesota, and, by 1946, the Federal Communications Commission (FCC) had distributed over 200 licenses to colleges [65]. In turn, in Latin America, radio organizations are considered the pioneers of distance learning [66].

In Canada, radio education started in 1941. First, it was implemented in adults' teaching, i.e., the Canadian Association for Adult Education and the Federation of Agriculture initiated the Farm Radio Forum [41]. The series of radio broadcasts was coordinated by universities from all over the country.

\subsection{Europe}

The first educational radio program was organized in 1927 by the British Broadcasting Corporation (BBC), which became defunct in 1926 and was reestablished with the same name in 1927. It was led by the Professor of Music at Gresham College, Walford Davies. This form of distance education was popular until 1969 when the British Open University (OU) was created [67]. In partnership with the BBC, the university created weekly radio programs that were integrated with printed course materials. It provided news information for OU students and allowed them to share their experiences and ideas. The course became popular, and it was presented weekly, along with a television adaptation. Ten years later, the course was switched from the radio and TV formats into audio cassettes.

Radio broadcasts were also a response to the lack of schools in rural Germany. The first educational broadcast was created in 1966 by the Hessian Broadcasting Corporation (Hessischer Rundfunk, Frankfurt, Germany) and the University of Frankfurt, with support from other universities and the German Institute for Distance Education (Deutsche Institut für Fernstudien or DIFF) at the University of Tübingen. Some of these educational broadcasts evolved into academic broadcasts and resulted in many students obtaining degree certificates. The era of educational radio broadcasting ended in Germany in 1998 [68]. 


\subsection{Australia}

The use of the radio for teaching in Australia was hampered by low population densities in many areas of the country. The first official radio lessons were transmitted on 8 June 1951, from the Royal Flying Doctor Service in Alice Springs to provincial children. Children using this system had the opportunity to ask the teacher questions and also to interact with other children [69]. This service was called the School of The Air (SOTA), and on 9 May 2001, it celebrated its 50th anniversary [70]. In 2005, there were more than sixteen Schools of the Air and Remote Learning located around Australia, a network covering more than 1.5 million square kilometers [71].

\subsection{Africa}

In 1962, after gaining independence, a Correspondence College, the "Centre d'Enseignement Superieur", was opened in Brazzaville, Congo. Teaching was conducted in French, and at the end of the 20th century, also in English. In 1974, the Government of Lesotho established the Lesotho Distance Teaching Centre (LDTC). This organization aimed to allow children and adults to learn to read, write, and count. In 1975, Nigeria followed Lesotho [72]. In the same year, the Institute of Adult Education and Distance Learning of Makerere University in Uganda was established.

\subsection{Asia}

In China in 1999, the Ministry of Education (MOE) launched a pilot project, which aimed to provide a distance education channel via the radio. It was initially supported by four universities: Tsinghua University, Zhejiang University, Beijing University of Posts and Telecommunications, and Hunan University [57].

\section{Television, Audio, and Videotape Cassettes}

Tape cassettes revolutionized the storage of sound data, using just a magnetic tape wound around two reels. They were invented by the Philips company in 1963 and named Compact Cassettes. They became a very popular way to listen to music and learn languages, and a revolution began in 1979 when Sony offered a portable, miniaturized cassette playerthe Walkman. In general, the arrival of tape cassettes improved distance learning. As a new technology, they enabled course delivery by post or from a store [38]. Cassettes promised a stress-free education, greater learning opportunities, the closing of the gap in society between the poor and the rich via a reduction in the cost of education, and the possibility to listen to and repeat the course at any time of the day. This type of education preserved most of the advantages provided by the mix of radio and paper handouts. This type of data storage was widely used in schools, as well as in homes. Both teachers and students could easily prepare their cassette tapes. Teachers could prepare tapes for use in direct vocational instruction and to give feedback on written work $[73,74]$. They were very popular, especially in language courses, offering the ability to practice skills, such as the pronunciation of a foreign language, over long distances. This form of education was very popular for over 20 years, thanks to its portability.

The 1990s brought about video cassettes, with a quality similar to that of the television. These offered a significant improvement over audio-only courses, as students were now able to see the teachers and the visual aids presented. Visual information became more efficient for learning than audio information due to the visual contact between the teacher and the learner. Therefore, very quickly, video cassettes became more popular than audio tape cassettes. They were small, portable, lightweight, and easily available. The sound quality was not quite as good as vinyl discs, but it was relatively close. The only limit was the amount of data that could be stored on a particular tape. Longer tape recordings could store lessons lasting 90 or $120 \mathrm{~min}$, while some other recordings were much shorter. Unfortunately, longer content required thinner tapes, which were more susceptible to breaking. Tapes were made with magnetic materials, such as magnetite (iron oxide), with cobalt additives, making them more elastic than older tapes, which mainly used chromium 
dioxide. Some tapes had a recording on both sides, which enabled the addition of more content. However, the magnetic material tended to leak out, shortening the life span of such tapes. Audiotapes were very popular for a long time. However, their final incarnation, in which they were modified with metal covers, made them more expensive. This was a crucial factor that lowered their position in the global distance education market.

\subsection{America}

In the early 1900s, attempts to include visual communication in the training process began. The first scientific unit that provided courses by television was the University of Iowa, United States of America, in 1934 [75]. Initially, problems such as interference and band allocation issues appeared. In 1950m scientific bodies noticed the incredible potential of television as a means of transferring knowledge, but not in the case of distance learning. Teachers used the television in the classroom as a tool to demonstrate and explain concepts, while citizens watched educational broadcasts at home. In 1952, special channels were reserved purely for educational purposes. In 1967, following recommendations by the Carnegie Commission on Educational Television, the Corporation for Public Broadcasting (CPB) was established [76]. In 1968, the Instructional Television Network was created at Stanford University. It provided instructions for part-time engineering students [77]. However, teachers were still reluctant to use television as a means of distance learning. In 1980, the first state educational satellite system, Learn/Alaska, was created. It provided six hours of instructional television a day to about 100 villages [78].

The huge demand for distance learning in Canada led to the creation of three units that deal solely with distance learning [41]. In 1972, Athabasca University (AU) was established. It enabled higher education in science and the arts via distance learning. In the same year, Télé-université in Québec was created. It offered university credit and noncredit courses throughout the province. In 1978, British Columbia brought to life the Open Learning Institute (OLI). These organizations ensured college, basic adult, technical, career, vocational, and university education to students throughout the province. In 1980, TV and Radio companies such as OLI, TVOntario, Radio-Québec, the Saskatchewan Communications Network (SCN), Northern Canada Television, and ACCESS Alberta delivered educational television programs to a wide range of audiences.

\subsection{Europe}

In Poland, in the early 1960s, the first educational television broadcasts for primary and secondary schools were released. In the years 1966-1971, television also entered higher education and the first television college, i.e., Television University, was established. This unit, which offered a combination of television learning and a correspondence course, was organized by Janusz Tymowski (Government Plenipotentiary for the Television) and Tadeusz Nowacki [42].

In Germany, in 1970, the University Association for Distance Education in Multimedia (Hochschulvereinigung für das Fernstudium im Medienverbund or HVF) was initiated. This organization gathered over 80 bodies dealing with education. These units developed common curricula, but the lack of common infrastructure led to a temporary suspension of their work. In response, in 1974, the state of North Rhine-Westphalia established the FernUniversität (Open University) in Hagen. This institution was modeled on Britain's Open University. Despite political opposition, the university is still growing rapidly and remains a leader in the provision of distance learning to this day. In competition to HVF was the so-called "experiment in distance education using multimedia systems" (Versuch für das Fernstudium im Medienverbund). However, as an attempt at providing relief for overpopulated universities, this experiment failed. The first private units offering distance learning services were established in the 1980s [68]. 


\subsection{Australia}

In 1973, the Australian Film Television and Radio School (AFTRS) was created. Since 1976, it has been known as the Australian Film Television School (AFTS), which is a screen art and broadcast school covering the whole country [79].

\subsection{Africa}

In 1997, in Africa, a mixed TV-telephone education system was created, the World Bank's African Virtual University (AVU). It enabled students in 16 African countries to take courses and seminars taught by professors from universities around the world [80]. Lecturers conducted classes in front of cameras and later broadcast them via satellite to African students. Students were able to ask lecturers questions using telephone lines.

\subsection{Asia}

Between 1979 and 1998, distance education took place in China via radio and television. In 1982, in Japan, the Open University of Japan (OUJ) was created [21]. It was modeled after the British Open University, but it had quite different aims. The mission of OUJ was to provide working people and housewives with the chance of lifelong university-level education. Teaching took place via the use of radio and television. In the beginning, only students from the Tokyo agglomeration were allowed to participate in the classes. Later, others were also permitted to join, but this required a special antenna and receiver. In 2006, OUJ switched to digital broadcasting.

In 1975, experimental satellite television began using this medium for distance learning. This first took place for agricultural and community education, along with Farm Radio. In 1984, the "Countrywide Classroom" television and video series was started. In 2005, a special educational satellite called EduSat was launched. The primary and secondary education sectors experimented with distance teaching technologies and implemented them much faster than the higher education sector [81].

From the point of view of teachers and students, remote learning by radio and television had one major drawback - one-sidedness. The listener is only a silent recipient of the broadcast and TV images. Only the use of a telephone enabled two-way communication. This form of communication was proposed for the first time in 1965 at the University of Wisconsin, USA [82]. The decade of the 1990s revolutionized teaching and learning due to the development of modern technologies like computers and the Internet. This revolution opened the doors of the classroom to everyone, no matter where they were.

\section{Floppy Disks and CD-ROMs}

Although audio and video cassette tapes were a revolutionary method for distance learning, they were replaced with floppy disks, which enabled the transfer of printed materials, as well as audio and video recordings, in an electronic, digital form, enabling the storage of information for use by the learner at any time. Distance learners could obtain more knowledge than from printed books and cassettes with the use of computers. This data storage medium quickly replaced them and became prevalent globally.

As floppy disks were on their way out, distance learning turned its attention to data storage media that could store much more data. Compact Disc Read Only Memories (CD-ROMs), also called CDs, lead to a decline in the popularity of audio cassettes, video cassettes, and floppy disks, offering cheaper production costs, longevity, better audio quality, and higher data storage capability. As the technology evolved in the 1990s, many schools and other institutions began using CD-ROMs to improve teaching. The format was even more suitable for distance learning over a flexible period of time than cassette tapes. CD-ROMs offered educational games, discoveries, educational movie courses, instructions, and exercises. It was possible to learn not only by listening, as in the case with the use of cassette tapes but also to interact with multimedia software. This software, available on CD-ROMs, became necessary for many institutions delivering lectures, tutorials, and even project work. 


\section{PLATO}

The invention and development of personal computers changed distance education forever. Educators are now able to create distance education electronic courses that can be delivered to several computers that are connected. The first system dedicated to that field was created at the University of Illinois in the 1960s [83,84]. It was named Programmed Logic for Automated Teaching Operations (PLATO) and consisted of computers that were distributed throughout the academic campus [82]. Over time, that system expanded and was connected to a high school in Illinois. Students were able to learn using PLATO through online forums, message boards, chatrooms, and remote screen sharing. Due to the expansion of the global Internet, the era of PLATO ended in 2006. However, PLATO was a precursor to today's online world of education.

\section{Internet}

The first computers were costly and cumbersome. They were challenging to maintain and required a dedicated, specialized operating staff. In practice, this limited access to computers to only a specific group of people, such as university personnel, government employees, larger businesses, and electronic hobbyists. Universal access to computers was initiated by the advent of the first solutions designed for personal use, i.e., Apple II in 1977, the IBM PC in 1981, the Apple Macintosh in 1984, and the Windows operating system in 1990 [85].

The rise of the Internet made it possible to conduct distance teaching in entirely new ways. Before the birth of the Internet, scientists predicted the existence of fiber-optic networks that would transmit information. J. C. R. Licklider proposed the general idea of an "Intergalactic Network" of computers in the early 1960s. Then, the development of the "packet switching" concept (the method for effectively transmitting electronic data) contributed to the foundation of today's Internet network. By the end of the 1960s, the Internet network's first working prototype appeared: the Advanced Research Projects Agency Network (ARPANET) [86,87]. This U.S. Department of Defense system used packet switching to allow multiple computers to communicate on a single network. In the 1980s, Tim Berners-Lee laid the foundations for today's web service. At that time, the web was a space where stored information could be found by entering a particular address. The first successful implementation of a data exchange public network was the French Minitel. An online, accessible video-text system was introduced in France in 1982 by France Télécom and La Poste $[88,89]$. A particular terminal was needed to use this system, consisting of a keyboard connected to a small monitor and a modem. Under the applied business model, these terminals were distributed for free by France Telecom, and only their use was associated with fees. Computers compatible with this system were also developed, e.g., Thomson TO7. Minitel operated until June 2012. In the 1980s, companies started using computer-based programs to train new employees [90]. The computer connection services allowed dial-up modem access, but still used proprietary networks. Some of the universities opened their isolated internal networks, which allowed faculty and students to communicate. A real breakthrough in service delivery was initiated by the hypertext language's development, dating back to 1990, and the first integrated web browser (Mosaic) in 1993 [91]. Figure 1 shows a schematic representation of distance learning via the Internet.

\subsection{America}

In 1989, online educational programs were launched at the University of Phoenix. They used CompuServe, which was one of the first online consumer services. In 1992, the Alfred P. Sloan Foundation developed the Asynchronous Learning Networks (ALN) as an educational alternative for people who could not attend traditional classes in a classroom [92]. Since the mid-1990s, universities and other scientific units have used the Internet application for the transfer of knowledge. The first significant university to introduce online courses was New York University (NYU) in 1998. Others followed soon after [93]. In turn, Jones International University, Colorado, launched five bachelor's 
degrees and 24 master's degree programs online. In 1997, the California Virtual Campus was formed, with the universities of Princeton, Stanford, and Yale forming a union offering online learning. Next, the University of Oxford also joined their union [94,95].

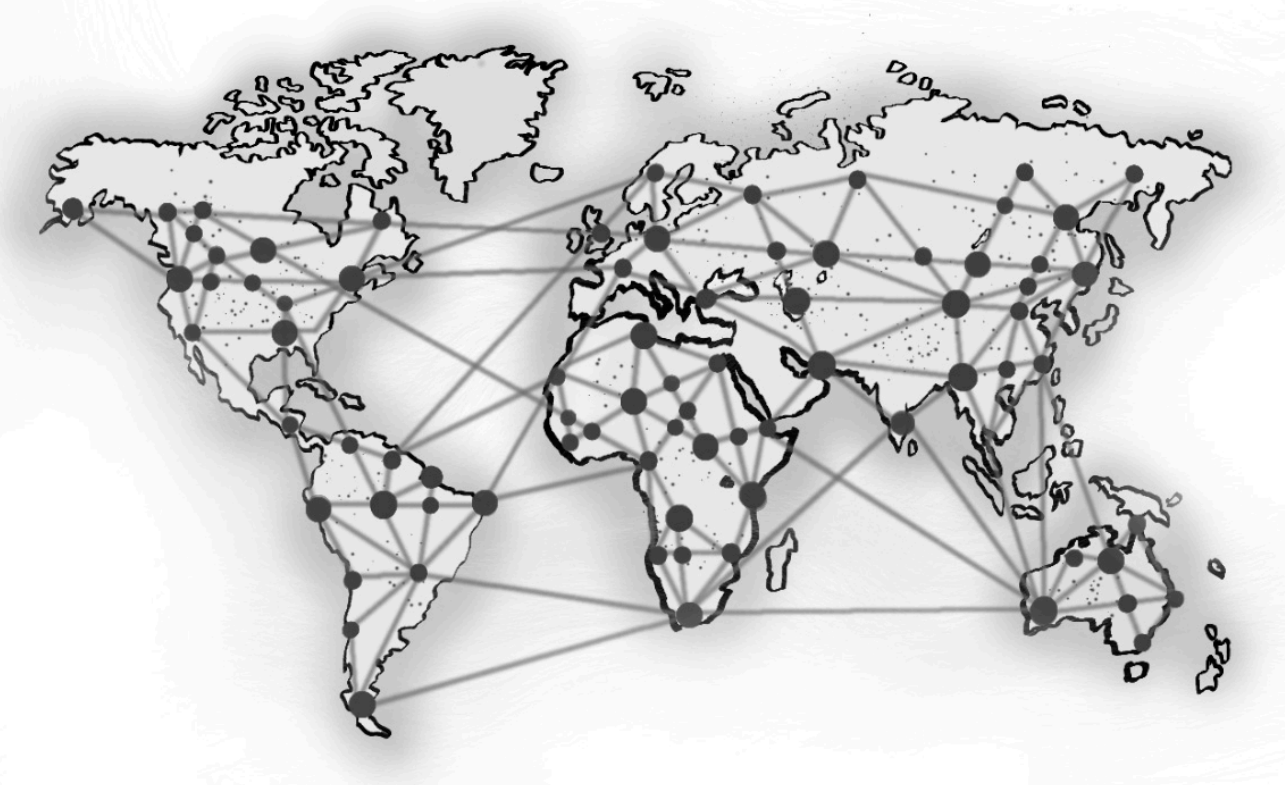

Figure 1. A schematic representation of global distance education (own sources).

In Canada, the first college that used the Internet as a learning source was OntarioLearn (1995) [41]. Other universities were quick also to adopt this approach: Campus Manitoba (1998), BCcampus (2002), and eCampus Alberta (2003).

\subsection{Europe}

In 1998, the British Open University and its American branch, the United States Open University, were established. The latter ended its activity in 2002 due to an insufficient number of participants.

The first online studies in Poland started in 1996 at the AGH University of Science and Technology in Cracow (Extramural Education Centre, currently E-Learning Centre), in 1999 at the University of Warsaw (an interdepartmental Centre of Open Multimedia Education), and in 2000 at the Warsaw University of Technology (Centre for Distance Education). In 2002, Maria Curie-Skłodowska University in Lublin and the High School of Humanistic and Economics in Łódź created the Polish Virtual University. The first courses covered topics from management and marketing to computer science, political sciences, and nursing. In 2001, the Warsaw School of Economics (SGH) enabled its students to attend classes and lectures online and download additional study materials. SGH's Extramural Education Development Centre shared these resources. In 2005, the Distance Learning Centre at the Jagiellonian University employed online learning using the BlackBoard and Modular Object-Oriented Dynamic Learning Environment (Moodle) platforms [42]. Other organizations have followed similar distance education schemes, with courses mostly based on the Moodle platform.

In Germany, virtual universities (and fusions between virtual and traditional universities) began to emerge in the 1990s as genuine university projects [96]. The university centers, such as those in Oldenburg, Lüneburg, Hildesheim, Kaiserslautern, Koblenz, or Karlsruhe, offer online instructional support programs, seminars, or multimedia educational materials [68]. 


\subsection{Australia}

In 2001, ICS Australia was renamed Thomson Education Direct, and distance learning focused on developing, sharing, and popularizing online courses. In 2007, this unit became part of the academic publishing company Cengage Learning and changed its name to Cengage Education. In 2011, the university was taken over by Nexus Education Group Pty Ltd. and renamed Open Colleges [51].

\subsection{Africa}

The World Bank's African Virtual University provides access to scientific journals, a digital library and working papers on the Internet. In 2005, the Institute of Adult Education and Distance Learning of Makerere University in Uganda opened a Ph.D. course taught via the Internet. A specialized e-learning system was also established, named the "Mobile Learning Model (MOLODUM)", designed to increase the interaction between on-site and distance learning [97], and was based on mobile phone applications. Soon, thanks to an organization called "Distance Education Association of Southern Africa" (DEASA), distance learning at both primary, secondary and tertiary levels was introduced to countries such as Botswana, Lesotho, Swaziland, Namibia, Malawi, Mozambique, Zambia, Angola, Tanzania, Zimbabwe, Mauritius, Seychelles, Madagascar, the Democratic Republic of Congo and South Africa. In fact, most of the countries in sub-Saharan Africa have taken an Internetbased approach to distance learning. For example, Ghana's government puts a great deal of stock in Internet-based education to ensure citizens' access to higher education [98].

\subsection{Asia}

In 1999, the Ministry of Education (MOE) launched a pilot study of distance learning via the Internet. It brought together six universities (Tsinghua University, Zhejiang University, Beijing University of Posts and Telecommunications, Hunan University, Central Radio and TV University (CRTVU) - currently the Open University of China (OUC)). All units contributed to a diploma degree in distance education. At the very beginning, Tsinghua University welcomed international students. Nowadays, the Beijing University of Posts and Telecommunications conducts remote education via the Internet but offers courses via the postal service. The activities of Zhejiang University and Hunan University were limited only to the respective provinces where they were located. The program expanded to 23 more bodies in the following years, thus moving education from the elite level to the general level [99]. In Japan, OUJ began making lectures available on the Internet in 2008 [58]. Since 2012, materials have also been available via mobile phones. In 2011, the Modular Object-Oriented Dynamic Learning Environment (Moodle)-based learning management system (LMS) was introduced. It enables students to ask and answer questions (mostly multiple-choice questions) online. This system is also used when constructing a master's thesis. In 2009, the Wakaba System was created. It allows students to access their grade records through a web browser and to register for courses online. In 2010, for the first time, OUJ students were provided with email accounts via Gmail.

Distance learning units in India have adapted to Internet-based learning over the years. The Indira Gandhi National Open University (IGNOU) developed a modular education system via the Internet, and provincial universities have adopted it. The course provided by IGNOU was supported by the Moodle learning management system [100].

In the Information Age, real-time video and audio communication are available thanks to the Internet [100]. In 2012, TEDEd launched educational videos from the world's top teachers for free [101]. Following the path taken by TEDEd, Course Hero curated and launched 22 free full-length courses [102]. This shows that the transformation of lectures to a digital format is of high importance. Such courses offer many advantages. They are free of charge, it is possible to access them in a flexible timeframe, and they offer equal access [103]. In many fields, it is hard to convert analogue knowledge into digital formats. For example, traditional practical anatomy training is nearly impossible to convert into an online-only version [104]. The same problem affects chemistry workshops and biology, and 
all other fields where students gain individual manual practice. The Internet began a new generation of distance learning technology, forcing universities to redesign many courses, delivering them using new tools. VR goggles are useful when teaching medical students, as learners can watch a simulated operation without putting patients at risk. However, alternative ways of teaching are needed to achieve similar learning outcomes as physical education $[105,106]$. Technologies based on Virtual, Augmented, or Mixed Realities seem to be a promising direction.

\section{Virtual, Augmented, and Mixed Realities}

Immersive technologies, such as Virtual Reality (VR), Augmented Reality (AR), and Mixed Reality (MR), have great potential to revolutionize education systems [107]. Virtual Reality is the creation of an artificial environment using computers. It includes the creation of objects, spaces, and events $[108,109]$. To participate, the user needs a head-mounted display (HMD) or headset. In turn, Augmented Reality enables users to partake in an interactive experience in two existing parallel worlds (real and computer-generated) by providing a composite view $[110,111]$. This technology enables users to display additional digital information in the real world. This could be in the form of pictures, 3D images, sounds, or text. Technology has recently taken a step further and made it possible to expand AR features, creating Mixed Reality [112]. MR enables users to actively interact with digital information mixed with the real world in real-time. The first MR immersion system was created using the Virtual Fixtures platform at Armstrong Laboratories in the USA. Thanks to the Head Mounted Displays (HDMs), such as Microsoft HoloLens [113], Magic Leap One [114], or AjnaLens [115], it is possible to implement such a technology in the teaching process. As a natural consequence of this, initial attempts to implement VR/AR/MR technologies have been made, including applications in fields such as engineering [116], physics [117], medical studies [118-120], and biology education [121].

The implementation of VR/AR/MR technologies in education is related to generational differences in communication and learning styles [122]. Millennials (generally considered to be people born from 1980 to 1994) are familiar with smartphones and tablets, but the signature technologies of Generation $\mathrm{Z}$ (generally considered to be people born after 1995) will be VR/AR/MR glasses and 3D printers.

\subsection{Virtual Reality}

Virtual Reality allows for a fully immersive simulator in which nothing is left of the real world. It involves the multimedia creation of objects, spaces, and events [123]. It also allows for the creation of a virtual laboratory, such as a physics, geography, chemistry, or biology classroom. Among this solution's huge advantages are the cost savings generated by avoiding the performance of expensive exercises in practice and, instead, simulating them in VR. This appeals primarily to areas such as medicine. Another benefit is connected to safety issues. For example, a VR chemistry laboratory enables students to observe a wide range of dangerous reactions, such as combustion, explosions, and others, safely [124]. VR aims to link both real-world classrooms and online distance learning via a single platform. An attempt at a pilot distance learning system that uses virtual technology was presented in [125]. Another prototype, the smartphone or Virtual Reality viewer (AulaVR), which allows students to participate in face-to-face distance learning, is described in [126]. Moreover, another interesting application of VR is the Cave Automatic Virtual Environment (CAVE). The user is located in a dedicated room in which unique displays act as walls and floors. There are also some applications related to cultural heritage education [127]. The application of VR in higher education was enthusiastically received by students [128]. Simultaneously, the hardware requirements and the enormous costs associated with this technology make it difficult to use VR in education on a mass scale. 


\subsection{Augmented Reality}

AR can positively impact students' academic performance and can be considered a useful anatomy teaching tool [129]. Augmented Reality was implemented in neuroanatomy teaching as two-part $1 \mathrm{~h}$ courses [130]. The first part included a medial lemniscal path to the primary somatosensory cortex. At the same time, the second part enabled the exploration of the flow of the cerebrospinal fluid from the ventricular system to the subarachnoid space. The participants were a group of 16 first-year medical students. As a result, more than 80 percent of students wanted to include AR in their traditional curriculum courses. AR was also implemented in courses for nurses [131]. A dedicated application enabled the anticipation of consecutive steps during medical operations. CAE Healthcare company introduced the Vimedix AR clinical training system, in which students can explore human anatomy in 3D. They can explore animated hearts, lungs, or abdomens and observe in real-time how the ultrasound beam cuts through the anatomy to generate an ultrasound image [132]. An interesting point of view was presented in [133]. The paper is presented in the form of an interview with medical doctors. One of them stated that AR technologies help students to understand spatial relationships, but they do have some disadvantages, such as mild eyestrain, headaches, or motion sickness in some students. In summary, Augmented Reality can be an effective tool that enables a better understanding of how to act in real situations, makes the theoretical content more attractive, and thus increases students' motivation and learning outcomes [134].

\subsection{Mixed Reality}

The first commercially available medical course based on MR technology was provided by Case Western Reserve University School of Medicine (Cleveland, OH, USA) in cooperation with the Cleveland Clinic (Cleveland, Ohio) in 2016 [135]. The application "HoloAnatomy" is based on a 3D holographic course of human anatomy using Microsoft HoloLens. This tool enables the users to rotate, inspect, and virtually dissect a whole body and parts to see and understand the structures, systems, and organs. The HoloAnatomy comparison to traditional cadaveric dissection was presented in [136]. This application was also one of 50 winners of a 2017 Digital Edge Award. In turn, Pearson proposed a learning tool for nurses and affiliated medical schools [137]. Digital Pages, a Brazilian company, developed the interactive "Next Surgery" application for planning operations using Microsoft HoloLens. The application uses holographic projections in planning surgical procedures. Next Motion, a France-based company, proposed an application designed to run on HoloLens and assist in the teaching of aesthetic medicine. The application guides the surgeon through the entire medical procedure while identifying the parts of the patient's body that should be treated and the risk areas to be avoided. Using a facial recognition system, the application applies an authentic 3D hologram tailored to the patient and tracks his movements to maintain the continuity of the image adjustment. This allows the surgeon to observe the veins, arteries, and muscles of the face, and, in cases of aesthetic medicine, also the sites of Botox injection. In [138], two Australian higher education classrooms in physiology and anatomy were analyzed, concentrating on students' perceptions. It was found that AR-supported lessons are more popular and effective than other forms of distance learning, but they come at a higher cost, as AR devices are somewhat expensive. Mixed Reality is used not only in universities, but also in primary, secondary, and high schools. For example, in a local primary school in Singapore, an application containing two Solar System and Plant System modules was developed.

\section{COVID-19 Pandemic and Distance Teaching Reality}

Before 2020, the main reason for distance education was either the remoteness of students from teaching centers or poverty. However, in 2020, to slow the spread of the COVID-19 pandemic, schools were forced to limit face-to-face teaching and move to the digital world, i.e., online remote learning, at least for a while [139]. This shift was very rapid and, in some ways, brutal: most schools and teaching institutions were not ready 
for this occurrence because remote education was not the expected standard for education. Governments of different countries put in place various countermeasures to protect citizens against the spread of the COVID-19 pandemic. These restrictions covered not only involved limitations on movement, covering the mouth and nose, introducing lockdowns, or closing facilities such as shopping malls or sports facilities, but also the closure of schools, kindergartens, and universities in many countries, making it necessary to introduce distance learning. Across the world, there are currently more than 1.2 billion children in 186 countries who are affected by school closures due to the pandemic [140]. Most European countries decided to close their schools as early as March 2020 and temporarily reintroduce full-time teaching due to distance learning limitations only as a top-down regulation [141,142].

On the other hand, the approach to closing these institutions differed depending on the country. Some countries decided to close only high schools and universities, while kindergartens and primary schools remained open. Other countries introduced a shift system for students or hybrid learning models. Two main approaches to the rapid emergency education response were observed. The first concerned countries where educational systems had the technical and institutional capacity before the pandemic, allowing them to implement remote learning quickly. These countries practically closed their schools overnight, and children were left to learn at home. The second model was introduced in countries that had no experience in distance education. These regions had to react quickly to these changes by adjusting their resources or simply building them from scratch. As such, not all distance learning models started in the same place.

In Sweden, such switching was obligatory only for upper secondary schools, while other schools were left to make their own decisions regarding the provision of education [143]. Education on all levels was plunged into chaos due to unclear regulations, a lack of remote learning tools, and the absence of appropriate training for teaching personnel. Schools and universities, which work remotely, use solutions based on remote communication platforms such as Zoom, Google Classroom, Microsoft Teams, D2L, and Edgenuity [144]. Some countries had a much easier transition to remote learning than others. For example, in Sweden, in 2016, almost all students used the Internet every day (about 98 percent). About 40 percent of adolescents owned multiple personal electronic devices, such as tablets, computers, and mobile phones [145]. Interestingly, distance education in secondary schools in Sweden was rare. After the lockdown was announced, schools switched to remote classes within one day, and $75 \%$ of students assessed that they were well prepared for remote learning [146].

Countries with a limited capacity for online teaching, or where this would be impossible, launched TV and radio teaching during the pandemic (e.g., Peru, Sierra Leone and Kenya). In Latvia, a dedicated educational video channel (tavaklase.lv) was created [147], and, in Poland, a program for students in grades 1-8 of primary school was broadcast from Monday to Friday on the public channels of Telewizja Polska (TVP) [148]. Furthermore, in Romania, a digital platform (digital.educred.ro) gathered relevant, validated, and recommended e-learning platforms and online learning resources in one place [149]. In some regions, additional support for the distance learning process was introduced, allowing teachers to contact students' families, making phone calls or home visits, and a free mobile application that allowed teacher-student interaction, e.g., in Sao Paulo state, Brazil [150].

Other countries, such as Luxembourg and Greece, introduced a rotational teaching model [151]. This allowed smaller groups of students to return to school at different times, thereby minimizing student-teacher interaction and mixing, thus reducing the transmission of COVID-19. As such, students were allocated specific days or weeks where some of them studied at school, and the rest studied remotely. Of course, the children who attended schools followed a robust full sanitary regime-wearing a mask, keeping a safe distance, and disinfecting their hands. Classes were also adequately prepared-children did not sit together at desks, and rooms were disinfected regularly. Some schools also decided that children would stay in classrooms during breaks to organize their movement. 
Some countries developed different learning scenarios depending on the number of cases of COVID-19 in the country, called traffic light systems (e.g., Norway, Belgium and Austria). Belgium introduced a traffic light system for schools based on four colors: green, yellow, orange, and red. In a situation where the "green scenario" is introduced, all students go to school, and only hand hygiene is enforced. Yellow introduces a hybrid model of teaching in high school and restrictions related to maintaining a social distance and students wearing a mask. When the number of cases increases dynamically, the orange scenario is introduced and a rotation system for all students is implemented. The red scenario is more restrictive than the orange, introducing stringent hygiene rules. In Belgium, the above-described restrictions did not apply to kindergartens and primary schools, which operated on ordinary principles, with only the hygiene rules being maintained [152].

Countries such as Croatia, Germany, and Poland, decided to introduce a hybrid teaching model. Kindergarten and primary school grades 1-3 were resumed, and education for the upper grades of primary and high school was introduced remotely, except for vocational courses and laboratory classes. Some universities also opted for such solutions, like Wroclaw University of Science and Technology or Jagiellonian University, Poland [153]. In turn, many universities, such as the Warsaw University of Technology, Poland, switched to remote learning by the end of the academic year.

Due to the European Commission data, schools in most of the European countries have digital strategies and agendas [154], which make it possible to maintain digital learning. Some general practical recommendations for schools, teachers, and students' families regarding education during the pandemic were also reported in the United Nations Educational, Scientific and Cultural Organization (UNESCO) report [155]. In many countries, schools and some universities were completely unprepared for such developments. Some teachers said they had received support, while others were left to fend for themselves, with no financial support for buying educational supplies and no training in using remote learning tools.

For example, outside Europe, an emergency policy for "Suspending Classes Without Stopping Learning" was introduced in China. In essence, this policy aimed to suspend face-to-face teaching and shift education into an online environment as smoothly as possible. Government regulations were implemented to prepare the necessary infrastructure (e.g., arranging appropriate access to network services) [156]. Appropriate training was also provided to teachers regarding the use of online learning platforms and methods. However, this implementation encountered issues; not everyone in China has access to fast broadband Internet, which is required for online education. According to the Chinese government's 2018-2020 plan, by 2020, 98 percent of the country's villages should have access to broadband Internet [153]. That leaves two percent of the population vulnerable to being left out of online education. In China, as of March 2020, Internet penetration was 64.5 percent, meaning a significant portion of the population still has no Internet access. This could hinder the implementation of online learning. In fact, in March 2020, only 46.8 percent of students used online education via the Internet [154].

Researchers attempted to analyze how lockdown and remote learning affected schools and academies. In [155], the impact of the blockade caused by the COVID-19 epidemic on higher education in the Czech Republic was examined. A survey concerning the ability to implement teaching online (at home) and the flexibility of institutions was conducted. Several remote learning techniques, such as streaming via Microsoft Teams, Zoom, prerecorded videos, as well as face-to-face and online teaching and online consultations, were considered. Moreover, technical equipment, the software used for remote communication and the strong tendency of academics to use other solutions than those that were recommended were taken into account. It was found that, while the institution had special software before the pandemic, the knowledge of how to use it was almost equal to zero. However, such a quick reaction to the situation would not have been possible if the software was not available. The study pointed out that the description of the learning process 
and its documentation is of high importance. The transformation of traditional lessons into fully remote classes requires lessons, schedules and learning activities to be changed.

In the context of the Arabian culture, the consequences of implementing distance learning as a countermeasure to the development of the COVID-19 pandemic were presented in [23]. The analysis carried out suggests that the society was able to adapt to the new prevailing rules. The factors that contributed to the discipline of society were related to the advancement in communication technology, the increasing strength of individualism, and the fear of being infected with an unknown virus. An interesting study was also conducted by the authors of [157]. The research survey considered a group of notary employees in Turkey, who voluntarily used a distance education platform. User satisfaction turned out to be strongly related to age, and factors such as gender, work duration in the profession, number of notary employees, educational level, and previous practice in distance education did not show significant differences. In turn, in [158], the status of Turkish secondary school education regarding distance education during the COVID-19 pandemic in Turkey was investigated. The study was based on the opinions and observations of teachers. It was found that the teaching staff had huge problems with the new teaching method and that they could not teach Turkish remotely in an acceptable manner.

While educators and academic theatres have experienced challenges during the COVID-19 pandemic, on the opposite side, we have pupils and students, and we should consider their difficulties, findings, and satisfaction in connection with remote learning. Currently, the world is struggling with the third wave of the pandemic and many countries have been forced to close their borders. A sense of fatigue among many students and teachers has been consistently growing. An analysis of two universities, one in China and one in South Korea, suggests that study satisfaction during the COVID-19 pandemic has decreased over time [159]. These results were unexpected, but students who were satisfied with the traditional way of learning were also satisfied with the remote form. International students were much more satisfied than domestic students.

Moreover, the effort that the tutors put into distance learning was strongly correlated with student learning satisfaction. However, the lack of physical contact negatively affected the students' sense of community and overall satisfaction. Despite being satisfied with the individual teaching mode, students began to see group work as a much less satisfying part of their online learning. Additionally, about 60 percent of students said they would like to learn online after the pandemic. In turn, 70 percent of India's agricultural students declared readiness for remote learning during the pandemic [160]. They preferred to use smartphones for online learning and attended the recorded classes with quizzes at the end. It was found that the flexibility and timing of remote courses for students from rural areas with broadband problems is a huge advantage. However, this type of study specificity, which requires practical classes, is only possible thanks to the hybrid learning model.

It is also worth stressing that growing Internet consumption and the advantage of online life over everyday life may lead to psychological and/or even psychiatric disorders [161], such as depression and anxiety, as well as harassment. Internet addiction has many similarities with addiction to the consumption of toxic substances. The results obtained suggest that the implementation of university educational programs to redirect addictive behaviors, which are a consequence of the Internet's excessive use, is of high importance. Initial research in this area was already carried out before the pandemic [162]. It was found that there is still a long way to go when it comes to perfecting remote learning in higher education.

Another important issue is connected with what we can observe during personal contact. During remote learning, children lack contact with their peers, especially the youngest students, who find it difficult to focus while learning on a computer, requiring the significant involvement of parents, who work simultaneously as the child is learning. Additionally, some children received a wholesome meal at school, which was often the only hot meal they received during the day in impoverished regions. As a result of the switch to remote learning, children have begun to lack adequate nutrition, which could translate 
into serious health problems. It should also be emphasized that a teacher who has direct physical contact with a student may notice that the child is a victim of domestic or school violence, or that he/she may suffer from psychological problems, such as depression or anxiety. Unfortunately, some of these problems may go unnoticed in distance learning, and the consequences can be dramatic [152].

\section{Discussion}

Distance education appeared for a distinct purpose [23]. It provided opportunities for students to participate in courses that were not available to some learners, due to the fact that the distance between their home and the nearest school was too far, or because the fees charged by other educational courses were too high. From its inception, this form of education offered much more to those who needed it than was visible at first glance. It offered everyone an equal chance, regardless of their wealth, culture, gender, or religious background, overcoming geographical and demographical challenges.

Technology and communication development has dramatically changed distance education in recent decades, making courses widely available and more attractive. It has improved the quality of distance courses, but, at the same time, despite the tremendous effort of distance educators, for some topics, opportunities to gain certain types of knowledge, such as practical knowledge, are limited [163-165].

Each form of distance education has two sides: strengths and limitations. Early forms, such as correspondence courses and pure audio broadcasts, suffered from multiple weaknesses that limited the effectiveness of learning and professional development [166]. Despite the implementation of well-planned courses filled with high-quality instructions, these courses were limited by several factors, primarily dependent on the target audience and the media used to provide the course [167]. The main issues were the lack of efficient monitoring and evaluation of learners, the lack of interactive tasks, and limited learner engagement [168]. Printed materials could be unattractive, especially when the course had a paucity of engaging content or learners who preferred abstraction instead of organized concepts. As fast as these courses appeared, they required improvement [169]. Audiobased courses, appearing as broadcast radio or tape/CD-ROM-based media, were more promising, offering interactive content delivery [170]. They combined the learner and the educator skills with hands-on development, enabling learning without textbooks or other resources, and visualization of the concepts being taught. However, that form of education also had many disadvantages, such as boredom while learning when broadcasts appeared daily, access to electronic media, limited interactive tasks, and a lack of interaction with classmates and educators [171]. Despite the fact that audio learning was supported with visualization, combining hands-on development, this form of education has a high risk of long-term dissatisfaction. Visual materials provided a combination of words and pictures, and their simultaneous presentation, instead of their separation. Simultaneously, even the aforementioned form of education had limitations, like the boredom of learners due to unequal attention being provided to all participants of the courses, a lack of interpersonal, direct interaction, and less efficient learning compared to a direct learning format [172]. This format also limited the learning of practical knowledge [173]. Learners could only obtain some theoretical knowledge and did not interact with classmates as in the traditional education system.

The next iteration of distance learning development made it possible to combine many teaching modes and even provided simultaneous contact with educators, offering flexibility regarding the time and place in which education could take place. Since mobile electronics are standard in everyday life, online learning became one of the popular forms of education. In many situations, it is the only opportunity for people to obtain some level of education. Now (not only during a pandemic) people can obtain a degree by studying online. This form of teaching, just like previous correspondence, audio, and visual modes, has its advantages and disadvantages, which are described below. 
Online learning offers broad access to education—not only during a pandemic —in specific geographical regions, and also for people with disabilities. Moreover, some people who could carry out their work remotely during the pandemic decided to move from the city to the countryside temporarily and, thanks to remote education, their children could live up to hundreds of $\mathrm{km}$ from their school and still obtain an education without having to change schools. Due to the economic crisis and, for example, the closure of restaurants, cinemas, etc., students who lost their jobs moved to their parents' homes to avoid having to pay rent and could also continue their education from various locations. Distance learning also offers flexibility-some schools or universities do not have a fixed timetable, or can set an individual teaching mode and decide on the dates of classes. Thanks to this solution, students can successfully combine their studies with full-time work and thus gain knowledge and professional experience simultaneously. Another advantage of online learning is its broad access. Course participants can live on the other side of the continent and study remotely without additional costs, such as travelling to the institution offering the course or renting a flat.

Moreover, online courses are very often recorded so that students can study anytime and anywhere. This allows people to participate in a more significant number of classes than in the case of full-time teaching. It also leads to time and money being saved. For parents, remote learning means that there is no need to drive their children to school, no traffic jams, less fuel consumption, and no carbon footprint! For students, there is also the possibility of living outside the university, translating into savings on the cost of renting a flat and buying food (outside large cities, food is often much cheaper). This form of distance education also requires being knowledgeable regarding new technologies. Students can also learn remotely by receiving training materials in a digital form, so there is no problem with accessing them, and they cannot be lost like notes. Working with a computer and acquiring the Internet skills necessary for remote learning is valuable, especially for the youngest students. This form of education also makes it possible to educate students from home, so teachers who cannot leave their families alone at home may teach from their own houses [168,171]. These are advantages, while each distance learning mode also has its disadvantages.

One of the most common ones is limited access to the broadband Internet. Course participants often do not have equal access to an efficient Internet connection, so participation in synchronous courses can be problematic. Additionally, the lack of physical interaction with teachers and other course participants cannot be substituted with sending an email. Individual attention makes it impossible to get immediate feedback when needed, and written words can be less efficient for explaining complicated topics than spoken words. Quite often, educators also have little time to deeply explain minor yet essential details or concepts of particular topics. Another limitation of online learning is a lack of motivation. Personal interactions in classical forms of education enable students to stay focused while learning much longer than during online courses, especially when they have non-interactive lecture forms without discussing ideas with course participants. Simultaneously, participants can be distracted by many factors-from electronic ones, such as advertisements, to more engaging content on other websites, social media, or factors in their environment, such as home duties. In distance learning, students' contact with each other and teachers is minimal. Students can meet after school if possible or communicate online, but this teaching method does not develop communication skills or teamwork skills. The lack of face-to-face interactions within the study environment and with fellow students makes it difficult to build relationships. New technologies for online learning help but also hinder. Unfortunately, more and more tools are being developed that make it possible for students to cheat on online exams or even impersonate other people. Therefore, many schools and universities decide to conduct exams in a stationary manner, which requires students to come to school or university in person. Remote teaching also does not work in situations where there is a need to carry out many practical exercises, e.g., welding, chemical experiments, etc. The difficulty, in this case, is the lack of access to materials 
and equipment at home. Of course, new technologies are introduced, such as AR and VR, but even the most modern simulators will not replace future doctors or pilots. Last but not least, distance education cannot be substituted in fields where practical knowledge is required, such as medicine, engineering, etc. [170].

Distance learning has changed in recent decades, becoming very popular, and is still a growing market. Its concepts have changed rapidly, but technological development still requires improvement and redesign for today's solutions and the solutions of the future. The pandemic is slowly changing the perception of distance learning by the public, especially employers, but there is still an opinion that a study completed remotely is less valuable than full-time education.

\section{Conclusions}

Surprisingly, distance learning is not a modern phenomenon. Before the age of computers, this form of education was possible via postal services. Much of the twentieth century's distance learning took place mainly via radio and television due to the highly accessible equipment and the fact that there were no additional expenses for learners. Unfortunately, the only way to ask a question or interact with the teacher was by sending a letter to the studio where the educational broadcast was performed. In recent years, rapid developments in communication technologies and computer systems have led to multimedia formats. As a result, distance education moved away from correspondence and radio to audio/video broadcasting, teleconferencing, computer-assisted instructions, e-learning/online learning, podcasting, or Virtual/Augmented/Mixed Realities.

Distance learning may offer many advantages over traditional face-to-face teaching and training. The most significant ones are place and time independence. Both enable students to learn at any time of the day, anywhere they are, resulting in the spread of education to remote areas and societies with very little time for traditional education.

We can be sure of one thing, however: the COVID-19 pandemic represented a genuine test for the e-learning formula, and different countries have coped to different degrees.

Distance education has many advantages, above all the quick access to materials, the ability to check the students' knowledge on an ongoing basis, the individualization of the learning process, the possibility of working in a group, and direct interaction between the student and the teacher. However, it must not be forgotten that one of the most significant advantages of full-time study is constant, direct contact between the student and lecturer. It is challenging to replace this, even with the latest technology, and the practical knowledge that is fundamental to several professions cannot be replaced. The teacher, especially in the early stages of education, such as elementary or high school, is responsible for teaching children. Often, through direct contact with the student and observation of their behavior, a teacher can assess whether a child has problems, e.g., at home or with friends, and can react quickly. Furthermore, a child studying at school has contact with their peers, which significantly impacts their development. Moreover, distance education cannot replace practical workshops, where manual skills are taught. However, it should be emphasized that, in situations where access to education is limited, e.g., by the COVID-19 pandemic, distance learning provides a worthwhile alternative.

Author Contributions: Conceptualization, A.P. and M.O.; methodology, M.G.; writing-original draft preparation, A.P., K.M., M.G., M.O.; writing—review and editing, A.P., M.O. All authors have read and agreed to the published version of the manuscript.

Funding: This research received no external funding.

Institutional Review Board Statement: Not applicable.

Informed Consent Statement: Not applicable.

Data Availability Statement: Not applicable.

Conflicts of Interest: The authors declare no conflict of interest. 


\section{References}

1. Bruder, I. Distance learning: What's holding back this boundless delivery system? Electron. Learn. 1989, 8, 30-35.

2. Nasrullah. Role of Multimedia Tutorials in Distance Education. Int. J. Infonomics 2014, 7, 933-941.

3. Shahabadi, M.M.; Uplane, M. Synchronous and asynchronous learning e-learning styles and academic performance of e-learner. Procedia Soc. Behav. Sci. 2015, 176, 125-138. [CrossRef]

4. Mayadas, F. Asynchronous Learning Networks: A Sloan Foundation Perspective. J. Asynchronous Learn. Netw. 1997, 1, 1-16. [CrossRef]

5. Allen, I.E.; Seaman, J. Going the Distance: Online Education in the United States. The Online Learning Consortium. 2011. Available online: http://sloanconsortium.org/publications/survey/going_distance_2011 (accessed on 13 January 2021).

6. Shelton, K.; Saltsman, G. An Administrator's Guide to Online Education; Information Age Publishing: Greenwich, CT, USA, 2005.

7. Coursera. Available online: https://www.coursera.org/ (accessed on 14 January 2021).

8. Thoms, B.; Eryilmaz, E. How media choice affects learner interactions in distance learning classes. Comput. Educ. 2014, 75, 112-126. [CrossRef]

9. McCoy, L.; Lewis, J.H.; Dalton, D. Gamification and multimedia for medical education: A landscape review. J. Am. Osteopath. Assoc. 2016, 16, 22-34. [CrossRef] [PubMed]

10. Urh, M.; Vukovic, G.; Jereb, E.; Pintar, R. The model for introduction of gamification into e-learning in higher education. Procedia Soc. Behav. Sci. 2015, 197, 388-397. [CrossRef]

11. Cakula, S.; Sedleniece, M. Development of personalized e-Learning model using methods of ontology. Procedia Comput. Sci. 2013, 26, 113-120. [CrossRef]

12. Verpoorten, D.; Glahn, C.; Kravcik, M.; Ternier, S.; Specht, M. Personalisation of Learning in Virtual Learning Environments. In Learning in the Synergy of Multiple Disciplines; Cress, U., Dimitrova, V., Specht, M., Eds.; EC-TEL 2009; Lecture Notes in Computer Science; Springer: Berlin/Heidelberg, Germany, 2009; p. 5794. [CrossRef]

13. Fraszczyk, A.; Piip, J. Barriers to eLearning in rail. Transp. Res. Procedia 2020, 48, 168-186. [CrossRef]

14. Nasongkhla, J.; Sujiva, A. Teacher Competency Development: Teaching with Tablet Technology through Classroom Innovative Action Research (CIAR) Coaching Process. Procedia Soc. Behav. Sci. 2015, 174, 992-999. [CrossRef]

15. Stotz, S.; Lee, J.S. Development of an online smartphone-based eLearning nutrition education program for low-income individuals. J. Nutr. Educ. Behav. 2018, 50, 90-95. [CrossRef] [PubMed]

16. Cotwright, C.J.; Bradley, H.; Celestin, N.; Hall, J.N.; Stotz, S.S.; Birch, L. Determination eLearning preferences to inform beverage policy training for early care and education teachers. J. Nutr. Educ. Behav. 2020, 52, 732-741. [CrossRef]

17. Kapenieks, A.; Zuga, B.; Gorbunovs, A.; Jirhensons, M.; Kapenieks, J., Sr.; Kapenieks, J., Jr.; Witolina, I.; Majore, G.; Jakobsone-Snepste, G.; Kudina, I.; et al. User behavior in multi-screen eLearning. Procedia Comput. Sci. 2015, 65, 761-767. [CrossRef]

18. Albó, L.; Hernández-Leo, D.; Moreno Oliver, V. Smartphones or laptops in the collaborative classroom? A study of video-based learning in higher education. Behav. Inf. Technol. 2019, 38, 637-649. [CrossRef]

19. Lee, E.A.L.; Wong, K.W.; Fung, C.C. Learning with Virtual Reality: Its Effects on Students with Different Learning Styles. In Transactions on Edutainment IV; Pan, Z., Cheok, A.D., Müller, W., Zhang, X., Wong, K., Eds.; Lecture Notes in Computer Science; Springer: Berlin/Heidelberg, Germany, 2010; p. 6250. [CrossRef]

20. Taxén, G.; Naeve, A. A system for exploring open issues in VR-based education. Comput. Graph. 2002, 26, 593-598. [CrossRef]

21. Sinsiani, A.M.; Obeidat, N.; Alshdaifat, E.; Elsalem, L.; Alwani, M.M.; Rawashdeh, R.; Fares, A.S.; Alalawne, T.; Tawalbeh, L.I. Distance education during the COVID-19 outbreak: A cross-sectional study among medical students in North Jordan. Ann. Med. Surg. 2020, 59, 186-194. [CrossRef]

22. Dhawan, S. Distance learning: A panacea in the times of COVID-19 crisis. J. Educ. Technol. Syst. 2020, 49, 5-22. [CrossRef]

23. Al Lily, A.E.; Ismail, A.F.; Abunasser, F.M.; Alhajhoj Alqahtani, R.H. Distance education as a response to pandemics: Coronavirus and Arab culture. Technol. Soc. 2020, 63, 101317. [CrossRef] [PubMed]

24. Armstrong-Mensah, E.; Ramsey-White, K.; Yankey, B.; Self-Brown, S. COVID-19 and Distance Learning: Effects on Georgia State University School of Public Health Students. Front. Public Health 2020, 8, 547. [CrossRef]

25. Arksey, H.; O’Malley, L. Scoping studies: Towards a methodological framework. Int. J. Soc. Res. Methodol. 2005, 8, 19-32. [CrossRef]

26. Colquhoun, H.L.; Levac, D.; O’Brien, K.K.; Straus, S.; Tricco, A.C.; Perrier, L.; Kastner, M.; Moher, D. Scoping reviews: Time for clarity in definition, methods, and reporting. J. Clin. Epidemiol. 2014, 67, 1291-1294. [CrossRef] [PubMed]

27. Pham, M.T.; Rajić, A.; Greig, J.D.; Sargeant, J.M.; Papadopoulos, A.; McEwen, S.A. A scoping review of scoping reviews: Advancing the approach and enhancing the consistency. Res. Synth. Methods 2014, 5, 371-385. [CrossRef]

28. Munn, Z.; Peters, M.D.J.; Stern, C.; Tufanari, C.; McArthur, A.; Aromataris, E. Systematic review or scoping review? Guidance for authors when choosing between a systematic or scoping review approach. BMC Med Res. Methodol. 2018, 18, 143. [CrossRef] [PubMed]

29. Morrou, H.I. A History of Education in Antiquity; University of Wisconsin Press: Madison, WI, USA, 1982.

30. Lagemann, E.C. An Elusive Science: The Troubling History of Education Research; University of Chicago Press: Chicago, IL, USA, 2002.

31. Philipps, C. Caleb Philipps. Teacher of the new method of shorthand. Boston Gaz. 1728, 436, 2. 
32. Clark, J.T. Chapter 62. In Distance Education in Clinical Engineering Handbook, 2nd ed.; Academic Press: Cambridge, MA, USA, 2019; pp. 410-415. [CrossRef]

33. Matthews, D. The origins of distance education and its use in the United States. Journal 1999, 27, 54-59.

34. Verduin, J.R.; Clark, T.A. Distance Education; Jossey-Bass Publishers: Oxford, UK, 1991.

35. Emmerson, A.M. A History of the Changes in Practices of Distance Education in the United States from 1852-2003. Ph.D. Thesis, Dowling College, New York, NY, USA, 2004.

36. Florida Chautauqua Assembly, Inc. Available online: https://web.archive.org/web/20080725194532/http://www.floridachauta uqua.org/about_chautauqua/history/history.htm (accessed on 18 January 2021).

37. Open Air Gospel. Further Notes of the Camp Meeting Session. A Notable Day in the Chautauqua Assembly. Cincinnati Daily Gazette, 14 August 1878; 7.

38. Harting, K.; Erthal, M.J. History of distance learning. Inf. Technol. Learn. Perform. J. 2005, 23, 35-44.

39. Schools Educators. Available online: https://education.qld.gov.au/schools-educators/distant-education/history (accessed on 18 January 2021).

40. National University Extension Association. Available online: https://snaccooperative.org/ark:/99166/w6g218jq (accessed on 18 January 2021).

41. The Canadian Encyclopedia. Available online: https://www.thecanadianencyclopedia.ca/en/article/distance-learning (accessed on 18 January 2021).

42. Tanaś, M. Distance Education as an Object of Study and Reflection of Pedagogy in Poland. Int. J. Electron. Telecommun. 2015, 61, 237-243. [CrossRef]

43. University of Wisconsin-Madison. Available online: https:// courses.dcs.wisc.edu/wp/ilinstructors/2019/07/25/a-history-ofcorrespondence-course-programs / (accessed on 18 January 2021).

44. Karauda, K. Historia w Perspektywie Edukacji Zdalnej (Distance Learning'u -DL). Kult. I Hist. 2001, 1, 26-31. Available online: www.kulturaihistoria.umcs.lublin.pl/archives/41 (accessed on 18 January 2021). (In Polish).

45. Jeremy Norman's History in Information. Available online: https: / / www.historyofinformation.com/detail.php?entryid=2420 (accessed on 18 January 2021).

46. Noffsinger, J.S. Correspondence Schools, Iyceums, Chatauguas; Macmillan: New York, NY, USA, 1926.

47. Chiappe, A.; Adame, S.I. Open Educational Practices: A learning way beyond free access knowledge. Ensaio: Avaliação e Politicas Públicas em Educação 2017, 26, 213-230. [CrossRef]

48. Anderson, T.; Elloumi, F. Issues in Distance Education, Theory and Practice of Online Learning; Athabasca University Press: Edmonton, AB, Canada, 2004; Available online: https:/ /www.aupress.ca/books/120146-the-theory-and-practice-of-online-learning/ (accessed on 18 January 2021).

49. Hermods. Available online: https://www.hermods.se/om-hermods/valkommen-till-hermods/var-historia/ (accessed on 25 February 2021).

50. Olivier, M. Monetizing French Distance Education. A Field Enquiry on Higher Education Value(s). In International Review of Research in Open and Distance Learning; Athabasca University Press: Athabasca, AB, Canada, 2014; p. 15. [CrossRef]

51. Open Colleges. Available online: https:/ / www.opencolleges.edu.au/about-us/our-history (accessed on 18 January 2021).

52. White, M. Distance Education in Australian higher education-A history. Distance Educ. 2009, 3, 255-278. [CrossRef]

53. Sydney Distance Education High School. Available online: https://sydneyh-d.schools.nsw.gov.au/about-our-school/history-of -distance-education--de-.html (accessed on 18 January 2021).

54. Stacey, E.; Visser, L. The history of distance education in Australia. Q. Rev. Distance Educ. 2005, 6, $253-259$.

55. Harry, K. Higher Education Through Open and Distance Learning; Commonwealth of Learning: Vancouver, BC, Canada, 2002.

56. University of Ghana. Available online: https://www.ug.edu.gh/distance/about/brief_history (accessed on 18 January 2021).

57. Li, W.; Chen, N. China. In Open and Distance Education in Asia, Africa and the Middle East; Zawacki-Richter, O., Qayyum, A., Eds.; SpringerBriefs in Education; Springer: Singapore, 2019. [CrossRef]

58. Intech Open. Available online: https://www.intechopen.com/books/distance-education/generations-of-distance-education-an d-challenges-of-distance-education-institutions-in-japanese-high (accessed on 18 January 2021).

59. Panda, S.; Garg, S. India. In Open and Distance Education in Asia, Africa and the Middle East; Zawacki-Richter, O., Qayyum, A., Eds.; SpringerBriefs in Education; Springer: Singapore, 2019. [CrossRef]

60. Government of India (GoI). Third Five-Year Plan; Planning Commission; Government of India: New Delhi, India, 1961.

61. Panda, S. Higher education at a distance and national development: Reflections on the Indian experience. Distance Educ. 2005, 26, 205-225. [CrossRef]

62. Annamalai University. Available online: https:/ /annamalaiuniversity.ac.in/ (accessed on 25 February 2021).

63. Engel, H.A. WHA, Wisconsin's Pioneer. Unpublished Manuscript; Wisconsin State Historical Society: Madison, WI, USA, 1936.

64. Johnson, H.A. American School of Air Finds Inspiration in Its Drive to Being Knowledge. Cleveland Plain Dealer, 18 October 1936; p. 25.

65. Wood, D.N.; Wylie, D.G. Educational Telecommunications; Wadsworth Publishing Company: Belmont, CA, USA, 1977.

66. Rumble, G. The Planning and Management of Distance Education; Croom Helm: London, UK, 1986.

67. Internet archives. Available online: https://web.archive.org/web/20030609192205/http://www.pbs.org/als/dlweek/history/i ndex.html (accessed on 18 January 2021). 
68. Kappel, H.H.; Lehmann, B.; Loeper, J. Distance Education at Conventional Universities in Germany. Int. Rev. Res. Open Distrib. Learn. 2002, 2. [CrossRef]

69. Royal Flying Doctor Service. Available online: https://www.flyingdoctor.org.au/about-the-rfds/history/ (accessed on 18 January 2021).

70. BBC News. Available online: http://news.bbc.co.uk/2/hi/asia-pacific/8493752.stm (accessed on 18 January 2021).

71. Black, R.G. The Story of Australia, Creative Commons Attribution 2.0; Creative Commons: Mountain View, CA, USA, 2012.

72. Intech Open Distance Education. Available online: https://www.intechopen.com/books/distance-education/open-and-distanc e-learning-achievements-and-challenges-in-a-devmeloping-sub-educational-sector-in-afr (accessed on 18 January 2021).

73. Kirschner, P.A.; van den Brink, H.; Meester, M. Audiotape feedback for essays in distance education. Innov. High. Educ. 1991, 15, 185-195. [CrossRef]

74. Cryer, P.; Kaikumba, N. Audio-cassette tape as a means of giving feedback on written work. Assesement Eval. High. Educ. 2010, 12, 148-153. [CrossRef]

75. Koenig, A.E.; Hill, R.B. The Farther Vision: Educational Television Today; The University of Wisconsin Press: Madison, WI, USA, 1967.

76. Buck, J. PTV-It tries harder. Springf. Repub. 1971, 85, 1.

77. Dawson, M. On PSU. Available online: https://news.psu.edu/story/496777/2017/12/11/academics/we-are-wherever-you-are -penn-state-marks-125-years-distance?utm_source=headlines\%20issue\&utm_medium=email\&utm_term=497602_TEXT\&ut m_content=10-29-2020-06-11\&utm_campaign=ditigal\%20learning (accessed on 18 January 2021).

78. Schlosser, C.A.; Anderson, M.L. Distance Education: Review of the Literature; (Report No. ISBN-0-89240-071-4); ERIC Document Reproduction Service ED 382 159; State University of Science and Technology: Ames, IA, USA, 1994.

79. Australian Film Television and Radio School. Available online: https://www.aftrs.edu.au/about/why-aftrs/our-history/ (accessed on 18 January 2021).

80. Harvard Business Review. Available online: https://hbr.org/1999/09/pioneering-distance-education-in-africa (accessed on 18 January 2021).

81. Chaudhary, S.; Panda, S. Educational television and teleconference. In Educational Media in Asia; Reddi, U.V., Mishra, S., Eds.; The Commonwealth of Learning: Vancouver, BC, Canada, 2005.

82. Straighterline. Available online: https://www.straighterline.com/blog/brief-history-online-learning-infographic/ (accessed on 18 January 2021).

83. Bitzer, D.; Braunfeld, P.; Lichtenberger, W. PLATO: An Automatic Teaching Device. IRE Trans. Educ. 1961, 4, 157-161. [CrossRef]

84. Joanne, T. The historical evolution of educational software. Eric Collect. 1991, ED349936, 1-19.

85. Jenkins, T.; Dankert, E. Results of a Three-Month PLATO Trial in Terms of Utilization and Student Attitudes. Educ. Technol. 1981, $21,44-47$.

86. Allan, R.A. A History of the Personal Computer: The People and the Technology, 1st ed.; Allan Publishing: Shepperton, UK, 2001.

87. Hauben, M. History of ARPANET. Available online: http:/ / www.dei.isep.ipp.pt/docs/arpa.html (accessed on 18 January 2021).

88. Roberts, L. The ARPANET and computer networks, session 3. In A History of Personal Workstations; Association for Computing Machinery: New York, NY, USA, 1988. [CrossRef]

89. Cats-Baril, W.; Jelassi, T. The French Videotex System Minitel: A Successful Implementation of a National Information Technology Infrastructure. Mis Q. 1994, 18, 1-20. [CrossRef]

90. Gonzalez, A.; Jouve, E. Minitel: Histoire du réseau télématique français. Flux 2002, 47, 84-89. [CrossRef]

91. Rudestam, K.E.; Schoenholtz-Read, J. Overview: The coming of age of adult online education. In Handbook of Online Learning: Innovations in Higher Education and Corporate Training; Rudestam, K., Schoenholtz-Read, J., Eds.; Sage Publications: London, UK, 2002.

92. Snow, W.H.; Coker, J.K. Distance Counselor Education: Past, Present, Future. Prof. Couns. 2020. [CrossRef]

93. Kentnor, H. Distance Education and the Evolution of Online Learning in the United States Hope Kentnor. Curric. Teach. Dialogue 2015, 17, 21-34.

94. Arenson, K. More colleges plunging into uncharted waters of on-line courses. New York Times, 2 November 1998 ; A16.

95. Chronicle of Higher Education. United States Open University announces it will close in June. Chronicle of Higher Education, 5 February 2002.

96. Chronicle of Higher Education. Oxford, Princeton, Stanford, and Yale plan distance-education venture. Chronicle of Higher Education, 6 October 2000.

97. Kappel, H.H. Das Ende des Funkkollegs. Von den Schwierigkeiten einer Bilanz nach 30 Jahren Medienverbund. AUE Hochsch. und Weit. Inf. 1997, 1, 3-7. Available online: http://www.irrodl.org/index.php/irrodl/article/view /62/127 (accessed on 18 January 2021).

98. Kisambira, E. Distance Learning at Makerere University Goes Cellular. 2008. Available online: www.elearning-africa.com (accessed on 25 February 2021).

99. Shrestha, G. Utilization of Information and Communications Technology for Education in Africa; UNESCO: Addis Ababa, Ethiopia, 12000.

100. Zawacki-Richter, O.; Qayyum, A. Open and Distance Education in Asia, Africa and the Middle East; Springer Nature: Basingstoke, UK, 2020. [CrossRef]

101. Mythili, G. India Gandhi National Open University-OER-based postgraduate diploma in e-learning. In Case Studies on OER-Based e-Learning; Naidu, S., Mishra, S., Eds.; Commonwealth Educational Media Centre for Asia: New Delhi, India, 2015. 
102. TED-Ed. Available online: https:/ / ed.ted.com/ (accessed on 18 January 2021).

103. Course Hero. Available online: https:/ / www.coursehero.com/ (accessed on 18 January 2021).

104. Gómez-Galán, J.; Lázaro-Pérez, C.; Martínez-López, J.Á.; López-Meneses, E. Measurement of the MOOC Phenomenon by Pre-Service Teachers: A Descriptive Case Study. Educ. Sci. 2020, 10, 215. [CrossRef]

105. Mian, A.; Khan, S. Medical education during pandemics: A UK perspective. BMC Med. 2020, 18, 100. [CrossRef] [PubMed]

106. Lo, S.; Sandel Abaker, A.S.; Quondamatteo, F.; Clancy, J.; Rea, P.; Marriott, M.; Chapman, P. Use of a virtual 3D anterolateral thigh model in medical education: Augmentation and not replacement of traditional teaching? J. Plast. Reconstr. Aesthetic Surg. 2020, 73, 269-275. [CrossRef] [PubMed]

107. Grainger, R.; Liu, G.; Geertshuis, S. Learning technologies: A medium for the transformation of medical education? Med Educ. 2020, 1-7. [CrossRef]

108. Hughes, C.E.; Stapleton, C.B.; Hughes, D.E.; Smith, E.M. Mixed reality in education, entertainment, and training. IEEE Comput. Graph. Appl. 2005, 25, 24-30. [CrossRef] [PubMed]

109. Minsky, M. Telepresence. Omni, June 1980; 45-52.

110. Sanchez-Vives, M.V.; Slater, M. From presence to consciousness through virtual reality. Nat. Rev. Neurosci. 2005, 6, 332-339. [CrossRef]

111. Slater, M.; Neyret, S.; Johnston, T.; Iruretagoyenal, G.; de la Campa Crespo, M.A.; Alabèrnia-Segura, M.; Spanlang, B.; Feixas, G. An experimental study of a virtual reality counseling paradigm using embodied self-dialogue. Sci. Rep. 2019, 9, 1090321. [CrossRef] [PubMed]

112. Azuma, R.T. A survey of augmented reality. Presence Teleoperators Virtual Environ. 1997, 6, 355-385. [CrossRef]

113. Azuma, R.T.; Baillot, Y.; Behringer, R.; Feiner, S.; Julier, S.; MacIntyre, B. Recent advances in augmented reality. IEEE Comput. Graph. Appl. 2001, 21, 34-47. [CrossRef]

114. Rokhsaritalemi, S.; Sadeghi-Niaraki, A.; Choi, S.M. A Review on Mixed Reality: Current Trends, Challenges and Prospects. Appl. Sci. 2020, 10, 636. [CrossRef]

115. Microsoft Hololens. Available online: https:/ /www.microsoft.com/pl-pl/hololens (accessed on 18 January 2021).

116. Aniwaa VR AR. Available online: https://www.aniwaa.com/product/vr-ar/magic-leap-one/ (accessed on 18 January 2021).

117. Aniwaa VR. Available online: https://www.aniwaa.com/product/vr-headsets/dimension-nxg-ajnalens/ (accessed on 18 January 2021).

118. Su, S.S.; Perry, V.; Bravo, L.; Kase, S.; Roy, H.; Cox, K.; Dasari, V.R. Virtual and Augmented Reality Applications to Support Data Analysis and Assessment of Science and Engineering. Comput. Sci. Eng. 2020, 22, 27-39. [CrossRef]

119. Thees, M.; Kapp, S.; Strzys, M.S.; Beil, F.; Lukowicz, P.; Kuhn, J. Effects of augmented reality on learning and cognitive load in university physics laboratory courses. Comput. Hum. Behav. 2020, 108, 106316. [CrossRef]

120. Vergel, R.S.; Morillo Tena, P.; Casas Yrurzum, S.; Cruz-Neira, C. A Comparative Evaluation of a Virtual Reality Table and a HoloLens-Based Augmented Reality System for Anatomy Training. IEEE Trans. Hum. Mach. Syst. 2020, 50, 337-348. [CrossRef]

121. Tang, K.S.; Cheng, D.L.; Mi, E.; Greenberg, P.B. Augmented reality in medical education: A systematic review, La réalité augmentée en formation médicale: Une revue systématique. Can. Med Educ. J. 2020, 11, e81-e96. [CrossRef]

122. Openrepository. Available online: https:/ /openrepository.aut.ac.nz/handle/10292/12089 (accessed on 18 January 2021).

123. Arslan, R.; Kofoğlu, M.; Dargut, C. Development of Augmented Reality Application for Biology Education. J. Turk. Sci. Educ. 2020, 17. [CrossRef]

124. Labovitz, J.; Hubbard, C. The Use of Virtual Reality in Podiatric Medical Education. Clin. Podiatr. Med. Surg. 2020, 37, 409-420. [CrossRef] [PubMed]

125. Chang, Z.Q.; Zhang, D.H.; Jin, X.X. Application of virtual reality technology in distance learning. iJET 2016, 11, 76-89. [CrossRef]

126. Yépez, J.; Guevara, L.; Guerrero, G. AulaVR: Virtual Reality, a telepresence technique applied to distance education. In Proceedings of the 15th Iberian Conference on Information Systems and Technologies (CISTI), Sevilla, Spain, 24-27 June 2020; pp. 1-5. [CrossRef]

127. Ott, M.; Pozzi, F. ICT and Cultural Heritage Education: Which Added Value? In WSKS 2008: Emerging Technologies and Information Systems for the Knowledge Society; Springer: Berlin/Heidelberg, Germany, 2008; pp. 131-138. [CrossRef]

128. Liu, Y.; Fan, X. Application of Virtual Reality Technology in Distance Higher Education. In Proceedings of the 2019 4th International Conference on Distance Education and Learning, Shanghai, China, 24-27 May 2019; pp. 35-39. [CrossRef]

129. Chytasa, D.; Johnson, E.O.; Piagkou, M.; Mazarakis, A.; Babis, G.C.; Chronopoulosc, E.; Nikolaou, V.S.; Lazaridis, N.; Natsis, K. The role of augmented reality in Anatomical education: An overview. Ann. Anat. 2020, 229, 151463. [CrossRef]

130. Weeks, K.J.; Amiel, J.M. Enhancing neuroanatomy education with augmented reality. Med Educ. 2019, 53, 516-517. [CrossRef]

131. Martin-Rodriguez, L.S.; Soto-Ruiz, M.N.; Echeverria-Ganuza, G.; Escalada-Hernandez, P. Augmented reality for training operating room scrub nurses. Med Educ. 2019, 53, 514-515. [CrossRef]

132. Mahmood, F.; Mahmood, E.; Dorfman, R.G.; Mitchell, J.; Mahmood, F.U.; Jones, S.B.; Matyal, R. Augmented reality and ultrasound education: Initial experience. J. Cardiothorac. Vasc. Anesth. 2018, 32, 1363-1367. [CrossRef]

133. Kuehn, B.M. Virtual and Augmented Reality Put a Twist on Medical Education. JAMA 2018, 319, 756-758. [CrossRef]

134. Gómez-Galán, J.; Vázquez-Cano, E.; Luque de la Rosa, A.; López-Meneses, E. Socio-Educational Impact of Augmented Reality (AR) in Sustainable Learning Ecologies: A Semantic Modeling Approach. Sustainability 2020, 12, 9116. [CrossRef] 
135. Digital Trends. Available online: https://www.digitaltrends.com/virtual-reality/hololens-holoanatomy-award-jackson-hole-sc ience-media-awards / (accessed on 18 January 2021).

136. Ruthberg, J.S.; Quereshy, H.A.; Ahmadmehrabi, S.; Trudeau, S.; Chaudry, E.; Hair, B.; Kominsky, A.; Otteson, T.D.; Bryson, P.C.; Mowry, S.E. A Multimodal Multi-Institutional Solution to Remote Medical Student Education for Otolaryngology During COVID-19. Otolaryngol. Head Neck Surg. 2020, 163, 707-709. [CrossRef]

137. Bin, S.; Masood, S.; Jung, Y. Chapter Twenty-Virtual and augmented reality in medicine. Biomed. Eng. 2020, 10, $673-686$.

138. Birt, J.; Stromberga, Z.; Cowling, M.; Moro, C. Mobile Mixed Reality for Experiential Learning and Simulation in Medical and Health Sciences Education. Information 2018, 9, 31. [CrossRef]

139. MacKenzie, D. Covid-19 goes global. New Sci. 2020, 245, 7. [CrossRef]

140. World Economic Forum. Available online: https://www.weforum.org/agenda/2020/04/coronavirus-education-global-covid19online-digital-learning/ (accessed on 25 February 2021).

141. An Official Website of the European Union. Available online: https:/ / eacea.ec.europa.eu/national-policies/eurydice/content/ how-covid-19-affecting-schools-europe_en (accessed on 25 February 2021).

142. Klimek-Tulwin, M.; Tulwin, T. Early school closures can reduce the first-wave of the COVID-19 pandemic development. J. Public Health 2020. [CrossRef]

143. Bergdahl, N.; Nouri, J. Covid-19 and Crisis-Promted Distance Education in Sweden. Tech. Know. Learn. 2020. [CrossRef]

144. PC World. Available online: https:/ / www.pcworld.com/article/3570614/what-remote-learning-will-look-like-this-fall-in-meetteams-and-zoom.html (accessed on 18 January 2021).

145. Internetstiftelsen. The Students and Internet. In Swedish Students' Internet Behaviours; Internetstiftelsen: Stockholm, Sweden, 2016.

146. Nilsson, L. Distance Education in High Schools in Sweden during Covid-19: Analysis of Students' Perceptions. Ph.D. Thesis, Karlstad University, Karlstad, Sweden, 2021.

147. Cedefop. Available online: https://www.cedefop.europa.eu/en/news-and-press/news/eu-countries-respond-effect-coronav irus-their-education-systems (accessed on 25 February 2021).

148. TVP. Available online: https://www.gov.pl/web/edukacja-i-nauka/szkola-z-tvp (accessed on 25 February 2021).

149. Edured. Available online: https://digital.educred.ro/ (accessed on 25 February 2021).

150. Wordbank Blogs. Available online: https://blogs.worldbank.org/education/changing-role-teachers-and-technologies-amidst-c ovid-19-pandemic-key-findings-cross (accessed on 25 February 2021).

151. Analysis COVID-19 Health System. Available online: https://analysis.covid19healthsystem.org/index.php/2020/09/15/what-s trategies-and-approaches-are-countries-implementing-within-schools-both-in-response-to-covid-19-and-to-localized-outbr eaks / (accessed on 25 February 2021).

152. Brussel Times. Available online: https://www.brusselstimes.com/belgium/123207/belgian-schools-could-remain-partially-clos ed-in-september/ (accessed on 25 February 2021).

153. Prawo. Available online: https://www.prawo.pl/student/studia-w-formule-hybrydowej-uczelnie-przygotowuja-sie-do-ro ku,502413.html (accessed on 25 February 2021).

154. European Commission 2nd Survey of Schools: ICT in Education Digital Single Market. Available online: https: / /ec.europa.eu/d igital-single-market/en/news/2nd-survey-schools-icteducation (accessed on 18 January 2021).

155. Doucet, A.; Netolicky, D.; Timmers, K.; Tuscano, J. Thinking about Pedagogy in an Unfolding Pandemic School Closures. Available online: https://issuu.com/educationinternational/docs/2020_research_covid-19_eng (accessed on 18 January 2021).

156. Yildiz, G.; Kilic Cakmak, E. Investigating the Distance Education Process According to the Demographic Characteristics of the Notary and the Notary Employee. Contemp. Educ. Technol. 2021, 13, ep293. [CrossRef]

157. Sügüumlü, Ü. A Case Study on Teaching Turkish through Distance Education. Int. J. Psychol. Educ. Stud. 2021, 8, 174-190. [CrossRef]

158. Fanguy, M.; Lee, S.Y.; Churchill, D.G. Adapting educational experiences for the chemists of tomorrow. Nat. Rev. Chem. 2021, 97, $1-2$.

159. Muthuprasad, T.; Aiswarya, S.; Aditya, K.S.; Jha, G.K. Students' perception and preference for online education in India during COVID-19 pandemic. Soc. Sci. Humanit. Open 2021, 3, 100101. [CrossRef]

160. Gómez-Galán, J.; Martínez-López, J.Á.; Lázaro-Pérez, C.; Sarasola Sánchez-Serrano, J.L. Social Networks Consumption and Addiction in College Students during the COVID-19 Pandemic: Educational Approach to Responsible Use. Sustainability 2020, 12, 7737. [CrossRef]

161. Gómez-Galán, J.; Martínez-López, J.Á.; Lázaro-Pérez, C.; García-Cabrero, J.C. Open Innovation during Web Surfing: Topics of Interest and Rejection by Latin American College Students. J. Open Innov. Technol. Mark. Complex. 2021, 7, 17. [CrossRef]

162. Haddad, M.; Ferreira, N.S.; Faria, A. The Use of Educational Technologies in Distance Education-Enabling the Appropriation of Teaching and Learning Process. Open J. Soc. Sci. 2014, 2, 54-58. [CrossRef]

163. Ryan, Y.; Latchem, C. Educational Technologies in Distance Education; John Wiley \& Sons: Hoboken, NJ, USA, 2016. [CrossRef]

164. Moore, R.; Fodrey, B. Distance Education and Technology Infrastructure: Strategies and Opportunities; Springer: Cham, Switzerland, 2018. [CrossRef]

165. Baum, S.; McPherson, M. The Human Factor: The Promise \& Limits of Online Education, Dædalus. J. Am. Acad. Arts Sci. 2019. [CrossRef] 
166. Tucker, S. Distance Education: Better, Worse, Or As Good As Traditional Education? Online Journal of Distance Learning Administration, Volume IV, Number IV, Winter 2001 State University of West Georgia, Distance Education Center. Available online: https://www.westga.edu/ \{\}distance/ojdla/winter44/tucker44.html (accessed on 25 February 2021).

167. Rapanta, C.; Botturi, L.; Goodyear, P.; Guàrdia, L.; Koole, M. Online University Teaching During and After the Covid-19 Crisis: Refocusing Teacher Presence and Learning Activity. Postdigit. Sci. Educ. 2020, 2, 923-945. [CrossRef]

168. Gregory, S.; Dalgarno, B.; Lee, M. Learning in Virtual Worlds: Research and applications; Athabasca University Press: Athabasca, AB, Canada, 2016.

169. Ioannidis, G.; Spiliotopoulou, G. Streaming Media in Education and Their Impact on Teaching and Learning; University of Patras: Patras, Greece, 2005.

170. Burns, M. Distance Education for Teacher Training: Modes, Models, and Methods; Education Development Center: Waltham, MA, USA, 2011; Available online: http://idd.edc.org/resources/publications/modes-models-and-methods (accessed on 25 February 2021).

171. Bambaeeroo, F.; Shokrpour, N. The impact of the teachers' non-verbal communication on success in teaching. J. Adv. Med. Educ. Prof. 2017, 5, 51-59. [PubMed]

172. eLearning Industry. Available online: https://elearningindustry.com/advantages-and-disadvantages-distance-education-offer (accessed on 25 February 2021).

173. Shih, T.; Hung, J. Future Directions in Distance Learning and Communication Technologies; IGI Global: Hershey, PA, USA, 2006. [CrossRef] 